Journal of Economic, Business and Accounting (COSTING)

Volume 2 Nomor 1, Juli-Desember 2018

e-ISSN : 2597-5234

https://doi.org/10.31539/costing.v2i1.375

IDMEKpe

\title{
PENGARUH STRUKTUR IKLAN TWO SIDED, PENGETAHUAN DAN PREFERENSI UNTUK PRODUK ROKOK TERHADAP MINAT BELI
}

\author{
THE EFFECT OF SIDED TWO AD STRUCTURE, KNOWLEDGE AND \\ PREFERENCE FOR CIGARETTE PRODUCTS TOWARD INTEREST TO BUY \\ ${ }^{1}$ Susianti, ${ }^{2}$ Samron Akhiri \\ ${ }^{1,2}$ STIE Prabumulih \\ sy40062@gmail.com
}

\begin{abstract}
Looking at cigarette product advertisements in various media, there is always a warning about the dangers of smoking to health in addition to information about the product itself. This study aims to identify the level of awareness and knowledge of consumers among smoker employees of PT. TEL Pulp and Paper on the influence of cigarettes on health, then continued by identifying the influence of cigarette advertisement structure on buying preferences, preferences and interests, and identifying whether there are significant differences in the assessment of advertising structure, level of awareness and knowledge, likes and preferences and beliefs and purchases between smokers based on differences in the number of cigarettes consumed per day. Hypothesis testing will be done by the Simple Linear Regression method. The results of the study show that From the output of the summary model, the determination table above gives $R$ Square of 0.824. This shows that the Two Sided Advertisements variable and knowledge and awareness simultaneously have an influence of 0.824 or $82.4 \%$ on buying interest, while the remaining $17.6 \%$ is the influence of (aspects) or other factors not included in the study this is like preferences and preferences etc. While the correlation value $(R)=0.769$. This shows that the Two Sided Advertisements variable and knowledge and awareness, the correlation is very strong against buying interest.
\end{abstract}

Keywords: Two-Sided Ad Structure, Awareness, Knowledge, Preference

\begin{abstract}
ABSTRAK
Mencermati iklan produk rokok di berbagai media, selalu terlihat adanya peringatan tentang bahaya merokok bagi kesehatan disamping informasi tentang produk itu sendiri. Penelitian ini bertujuan untuk mengidentifikasi tingkat kesadaran dan pengetahuan konsumen di kalangan karyawan perokok PT. TEL Pulp and Paper terhadap pengaruh rokok bagi kesehatan, kemudian dilanjut dengan mengidentifikasikan pengaruh struktur iklan rokok terhadap kesukaan, preferensi, dan minat beli, serta mengidentifikasi apakah ada perbedaan yang signifikan dalam penilaian terhadap struktur iklan, tingkat kesadaran dan pengetahuan, kesukaan dan preferensi serta keyakinan dan pembelian antara perokok berdasarkan perbedaan jumlah konsumsi rokok perhari. Pengujian hipotesis akan dilakukan dengan metode Simple Linear Regresion (Regresi Linear Berganda). Hasil penelitian menunjukkan bahwa Dari output model summary didapatkan tabel determinasi di atas yang memberikan $\mathrm{R}$ Square sebesar 0,824. Hal ini menunjukan bahwa variabel
\end{abstract}


Iklan Two Sided dan pengetahuan dan kesadaran secara simultan mempunyai pengaruh sebesar 0,824 atau 82,4\% terhadap minat beli, sedangkan sisanya sebesar 17,6\% merupakan pengaruh dari (aspek) atau faktor-faktor lain yang tidak termasuk dalam penelitian ini seperti kesukaan dan preferensi dll. Sedangkan nilai korelasinya $(\mathrm{R})=$ 0,769. Hal ini menunjukkan bahwa variabel Iklan Two Sided dan pengetahuan dan kesadaran, korelasinya sangat kuat sekali terhadap minat beli.

Kata Kunci : Struktur Iklan Two Sided, Kesadaran, Pengetahuan, Preferensi, Kesukaan

\section{PENDAHULUAN}

Pandangan yang kritis dalam melihat iklan, yaitu pandangan yang mengatakan bahwa iklan adalah mesin perpanjangan kapitalisme dimana terdapat sedikit ruang untuk memberikan pembelajaran, berpendapat bahwa sebuah iklan produk tidak lagi hanya sekedar memberikan informasi melainkan memberikan imaji baru atas suatu produk (Adiputra, 2011). Mengacu pada kasus Marlboro, ketika pertama kali hadir, rokok ini ditujukan untuk wanita karena kalah bersaing dengan Lucky Strike bila ditujukan untuk pria. Tetapi dengan rencana pemasaran yang hebat, dengan periklanan termasuk di dalamnya, Marlboro berhasil memenangkan pasar rokok pria karena mengidentikkan dirinya dengan kebebasan dan kejantanan yang direpresentasikan oleh koboi-koboi Amerika.

Realitas kondisi industri rokok di Indonesia selama ini terkesan kontroversial. Di satu sisi Karena tingginya beban penerimaan cukai rokok mendorong pemerintah untuk terus meningkatkan besarnya ketentuan tarif cukai, namun disisi lain desakan masyarakat luas untuk hidup sehat tanpa rokok juga sangat tinggi. Akibatnya, pemerintah juga harus ikut mendorong pengetatan peraturan mengenai iklan produk rokok ini, baik di media cetak maupun elektronik.
Tidak dapat dipungkiri bahwa sebuah iklan memang digagas untuk memperoleh keuntungan yang diperoleh dari adanya penjualan (sales). Namun ada hal-hal lain yang harus diperhatikan sebelum mencapai tujuan memperoleh keuntungan ini misalnya adalah menyadari adanya konsep social marketing, dimana perusahaan tidak hanya berusaha memuaskan konsumen sebagai upaya meraih profit yang diinginkan, tetapi juga harus menyadari akibat yang timbul dari kegiatan yang dilaksanakan.

Mencermati iklan produk rokok di berbagai media, selalu terlihat adanya peringatan tentang bahaya merokok bagi kesehatan disamping informasi tentang produk itu sendiri. Hal ini merupakan salah satu bentuk penerapan dari peraturan pemerintah tentang pengamanan rokok bagi kesehatan yang sudah disebutkan di atas, sehingga merupakan kewajiban bagi produsen rokok untuk selalu menampilkan informasi tentang bahaya merokok bagi kesehatan. Hal ini menjadikan setiap pesan iklan produk rokok tergolong sebagai iklan jenis two sides.

Iklan two sides dipandang lebih kredibel dan juga lebih efektif untuk meningkatkan prestasi merek yang diiklankan pada atribut primernya (Etgar dan Goodwin, 2000 dalam pechmann, 2005). Sebagian orang beranggapan bahwa penyajian sepihak (One sided 
presentation) yang memuji keunggulankeunggulan suatu produk akan lebih efektif dibandingkan dengan argumen dua pihak (two sided arguments) yang juga menunjukkan kekurangan produk. Namun iklan two sided tersebut mungkin akan lebih tepat dalam situasi tertentu terutama jika kesan negatif harus dihindari (Kotler, 2013)

Hipotesis yang akan diuji kebenarannya dalam penelitian ini adalah :

H1 : Diduga struktur iklan, tingkat kesadaran dan pengetahuan, kesukaan dan preferensi secara bersama-sama berpengaruh terhadap minat beli pada karyawan PT. TEL Kabupaten Muara Enim.

H2 : Diduga Struktur iklan untuk produk rokok berpengaruh terhadap minat beli pada karyawan PT. TEL Kabupaten Muara Enim.

H3 : Diduga tingkat kesadaran dan pengetahuan untuk produk rokok berpengaruh terhadap minat beli pada karyawan PT. TEL Kabupaten Muara Enim.

H4 : Diduga kesukaan dan preferensi untuk produk rokok berpengaruh terhadap minat beli pada karyawan PT. TEL Kabupaten Muara Enim.

\section{METODE PENELITIAN \\ Tempat dan Waktu Penelitian}

Penelitian ini dilaksanakan di PT. Tanjung Enim Lestari Pulp and Paper Kabupaten Muara Enim Provinsi Sumatera Selatan. Penelitian ini dilaksanakan pada bulan Maret sampai dengan bulan Oktober 2018. Penentuan lokasi dilakukan dengan sengaja (purposive) dengan pertimbangan bahwa PT. Tanjung Enim Lestari Pulp and Paper Kabupaten Muara Enim Provinsi Sumatera Selatan merupakan salah satu perusahaan pabrik kertas termasuk terbesar dengan populasi yang besar dan beranekaragam dalam hal departemen dan bagian.

Metode yang digunakan dalam penelitian ini adalah metode survey. Data yang dikumpulkan terdiri dari data primer dan data sekunder. Data primer diperoleh melalui metode wawancara yang dilengkapi dengan kuisioner yang telah disiapkan. Data sekunder diperoleh dari lembaga yang terkait, serta beberapa sumber pustaka baik berupa jurnal maupun buku yang berhubungan dengan penelitian ini.

\section{Penarikan Sampel}

Populasi dari penelitian ini adalah seluruh karyawan PT. TEL Pulp and Paper Kabupaten Muara Enim, perokok dan tinggal di Perumahan atau pabrik. Sedangkan sampel penelitian adalah sejumlah karyawan PT. TEL Pulp and Paper Kabupaten Muara Enim, perokok dan tinggal di Perumahan atau pabrik PT. TEL. Pengambilan sampel dilakukan dengan menggunakan metode nonprobability sampling berupa convenience sampling, yaitu sebuah cara pengambilan sampel dengan mendapatkan informasi melalui sumber yang tepat yaitu berdasarkan ciri-ciri tertentu yang dipandang mempunyai hubungan erat dengan ciri-ciri populasi yang telah diketahui. Metode ini digunakan sebab jumlah populasi karyawan perokok karyawan PT. TEL Kabupaten Muara Enim yang berdomosili di Perumahan atau pabrik PT. TEL belum diketahui sehingga sampel dipilih dari individu yang mudah diakses. Teknik pengambilan sampel yang digunakan dalam penelitian ini adalah nonprobability sampling yaitu teknik pengambilan sampel dengan cara tidak 
acak dan tidak memberi kesempatan bagi semua karyawan untuk menjadi sampel penelitian

(Sugiyono, 2013).

\section{Partisipan}

Partisipan adalah orang yang dapat memberikan informasi yang diperlukan (Moleong, 2014). Pemilihan partisipan dalam penelitian ini menggunakan teknik purposive, dimana partisipan yang dipilih sesuai dengan kriteria dan tujuan penelitian (Speziale \& Carpenter, 2003). Adapun kriteria partisipan dalam penelitian ini adalah karyawan PT. TELL Pulp and Paper Kabupaten Muara Enim Tahun 2018. Jumlah partisipan penelitian disajikan pada Tabel 1.

Tabel 1

Jumlah Partisipan Penelitian

Bagian Jumlah

Karyawan

HRD 150

Maintenance $\quad 150$

Produksi 250

Engenering 250

Total 800

Sumber: PT. TEL Pulp and paper

Metode penarikan contoh

dalam penelitian ini adalah metode Acak Sederhana (Simple Random sampling). Jumlah sampel sebanyak 100 responden yang dipilih secara acak dan diperoleh melalui hasil perhitungan dengan rumus Slovin, dimana jumlah karyawan di PT. Tanjung Enim Lestari Pulp and Paper yang perokok sebesar 800 populasi dengan nilai kritis yang digunakan adalah 10 persen (Umar, 2012).

Penentuan jumlah sampel tersebut disajikan sebagai berikut :

$$
\mathrm{n}=\frac{N}{1+N e^{2}}
$$

Keterangan:

$\mathrm{n}=$ Jumlah Sampel

$\mathrm{N}=$ Jumlah Populasi yang diketahui

$\mathrm{e}=$ error level (tingkat kesalahan),

$1 \%$ atau $0,01,5 \%$ atau 0,05 , dan

$10 \%$ atau 0,1 .

$$
\left.\mathrm{n}=\frac{800}{(1+800.10 \%} \%^{2}\right)=88,9
$$

Berdasarkan jumlah populasi $(\mathrm{N})=$ 800 orang, penentuan jumlah sampel didapat dengan menggunakan rumus formula diatas maka jumlah sampel dari populasi $(\mathrm{N})=800$ orang dengan error level $10 \%$, yaitu 88,9 atau dibulatkan menjadi 90 sampel.

\section{Uji Asumsi Klasik}

Uji Asumsi Klasik harus dilakukan untuk menguji layak tidaknya model analisis regresi yang digunakan dalam penelitian sehingga hasil penelitian dapat menghasilkan analisis regresi linier yang baik. Uji ini meliputi:

\section{Uji Normalitas Data}

Bertujuan untuk menguji tingkat kenormalan distribusi data pada variabel terikat dan variabel bebas. Menurut Ghozali (2013:30) model regresi yang baik adalah yang memiliki distribusi data normal atau mendekati normal. Distribusi data yang normal dilihat dari penyebaran data pada sumbu diagonal dari grafik Normal P-Plot.

\section{Uji Multikolinieritas}

Bertujuan untuk menguji ada tidaknya korelasi antara variabel bebas. Multikolonieritas dideteksi dengan menggunakan nilai variance inflation factor (VIF). Salah satu rujukan nilai yang digunakan adalah nilai VIF dibawah 10. Ghozali (2014:92). Model regresi yang baik mensyaratkan tidak terjadinya multikolinieritas. 


\section{Uji Heteroskedastisitas}

Bertujuan untuk menguji apakah dalam model regresi terjadi ketidaksamaan varian dari residual satu pengamatan ke pengamatan yang lain. Model regresi mensyaratkan tidak terjadi heteroskedastisitas. Salah satu cara untuk mendekati heteroskedastisitas adalah dengan melihat grafik scatter plot antara nilai prediksi variabel terikat (ZPRED) dengan residualnya (SRESID).

Analisis Regresi Linear Berganda

Analisis regresi linear berganda digunakan untuk mengetahui hubungan antar variabel yang diteliti. Pengujian hipotesis dilakukan dengan persamaan regresi berganda, dengan rumus: yang dinyatakan dengan rumus (Djarwanto PS dan Subagyo, 2008:315) :

$$
\mathrm{Y}=\mathrm{a}+\mathrm{b}_{1} \mathrm{x}_{1}+\mathrm{b}_{2} \mathrm{x}_{2}+\mathrm{b}_{3} \mathrm{x}_{3}+\varepsilon
$$

Dimana:

$\mathrm{Y}=$ Minat Beli

$\mathrm{a}=$ Konstanta

$\mathrm{X}_{1}=$ Struktur Iklan Two Sided

$\mathrm{X}_{2}=$ Pengetahuan dan Kesadaran

$\mathrm{X}_{3}=$ Preferensi dan Kesukaan

$\mathrm{b}_{1}=$ Koefisien Regresi dari Struktur Iklan

Two Sided

$\mathrm{b}_{2}=$ Koefisien Regresi dari Pengetahuan dan Kesadaran

$\mathrm{b}_{3}=$ Koefisien Regresi dari Preferensi dan

Kesukaan

$\mathrm{e}=$ standard error

\section{Teknik Pengujian Hipotesis}

Teknik analisis data yang digunakan penulis adalah analisis data kuantitatif dengan bantuan statistik menggunakan aplikasi SPSS Versi 21. Hipotesis yang digunakan penulis akan diuji dengan menggunakan teknik Analisis regresi linear berganda, Uji t, Uji F.

\section{Uji t ( Regresi parsial )}

Uji $t$ digunakan untuk mengetahui tingkat signifikansi pengaruh variabel bebas terhadap variabel terikat secara parsial atau terpisah.

1) Menentukan formulasi hipotesis Ho : b1, b2 = 0 artinya, tidak ada pengaruh dari masing-masing variabel bebas (x) terhadap variabel terikat ( y ).

$\mathrm{Ha}: \mathrm{b} 1, \mathrm{~b} 2 \neq 0$ artinya, ada pengaruh dari masing-masing variabel bebas ( $\mathrm{x}$ ) terhadap variabel terikat ( y ).

2) Menentukan derajat kepercayaan $95 \%(\alpha=0.05)$.

3) Menentukan signifikansi nilai signifikansi ( $P$ value $) \leq 0,05$, maka Ho ditolak dan Ha diterima. nilai signifikansi ( $P$ value $)>0,05$, maka Ho diterima dan Ha ditolak.

\section{Uji F ( Regresi simultan )}

Uji F digunakan untuk mengetahui tingkat siginifikansi pengaruh variabel- variabel bebas secara bersama-sama (simultan) terhadap variabel terikat.

1. Menentukan formulasi hipotesis Ho : $\mathrm{b} 1=\mathrm{b} 2=0$ artinya, semua variabel bebas ( $\mathrm{x}$ ) secara simultan tidak mempengaruhi variabel terikat ( y).

Ha : $\mathrm{b} 1=\mathrm{b} 2 \neq 0$ artinya, semua varibel bebas ( $\mathrm{x}$ ) secara simultan mempengaruhi variabel terikat ( $\mathrm{y}$ ).

2. Menentukan derajat kepercayaan $95 \%(\alpha=0,05)$.

3. Menentukan signifikansi

nilai signifikansi ( $P$ valu $e) \leq 0,05$, maka Ho ditolak dan Ha diterima. nilai signifikansi ( $P$ value $)>0,05$, maka Ho diterima dan Ha ditolak. 
Analisis Koefisien Determinasi $\left(\mathbf{R}^{2}\right)$

Analisis koefisien determinasi digunakan untuk mengetahui presentase sumbangan pengaruh variabel bebas secara bersama-sama terhadap variabel terikat. Koefisien determinasi menunjukkan seberapa besar presentase variasi variabel bebas yang digunakan dalam model mampu menjelaskan variasi variabel terikat. $\mathrm{R}^{2}=$ 0 , maka tidak ada sedikitpun presentase sumbangan pengaruh yang diberikan variabel bebas terhadap variabel terikat. Sebaliknya $\mathrm{R}^{2}=1$, maka presentase sumbangan pengaruh yang diberikan variabel bebas terhadap variabel terikat adalah sempurna, atau variasi variabel bebas yang digunakan dalam model menjelaskan $100 \%$ variasi variabel terikat.

\section{Kerangka Konsep Penelitian}

Dalam penelitian yang dilakukan ini, dapat disusun sebuah kerangka konsep penelitian yang dapat memberikan gambaran mengenai keseluruhan dari penelitian yang sedang dilakukan. Penelitian dimulai dari observasi terhadap konsumen yang merokok yang merupakan obyek dalam penelitian ini. Kemudian konsumen perokok tersebut diberikan sejumlah kuesioner yang menggambarkan perspektif konsumen terhadap struktur iklan two sided pengetahuan dan preferensi mereka terhadap suatu produk rokok. Dari perspektif yang dituangkan dalam sebuah kuesioner tersebut akan diambil kesimpulan mengenai 3 macam aspek yang menjadi indikator pengambilan kesimpulan dan tujuan dari penelitian ini. Aspek-aspek tersebut adalah aspek kognitif (kesadaran konsumen dalam membeli rokok \&pengetahuan konsumen dalam memutuskan membeli rokok), aspek afektif (kesukaan konsumen dalam membeli rokok \& preferensi konsumen dalam membeli rokok), dan aspek konatif (keyakinan konsumen dalam membeli rokok \& minat beli konsumen terhadap rokok). Dapat dilihat pada gambar 1

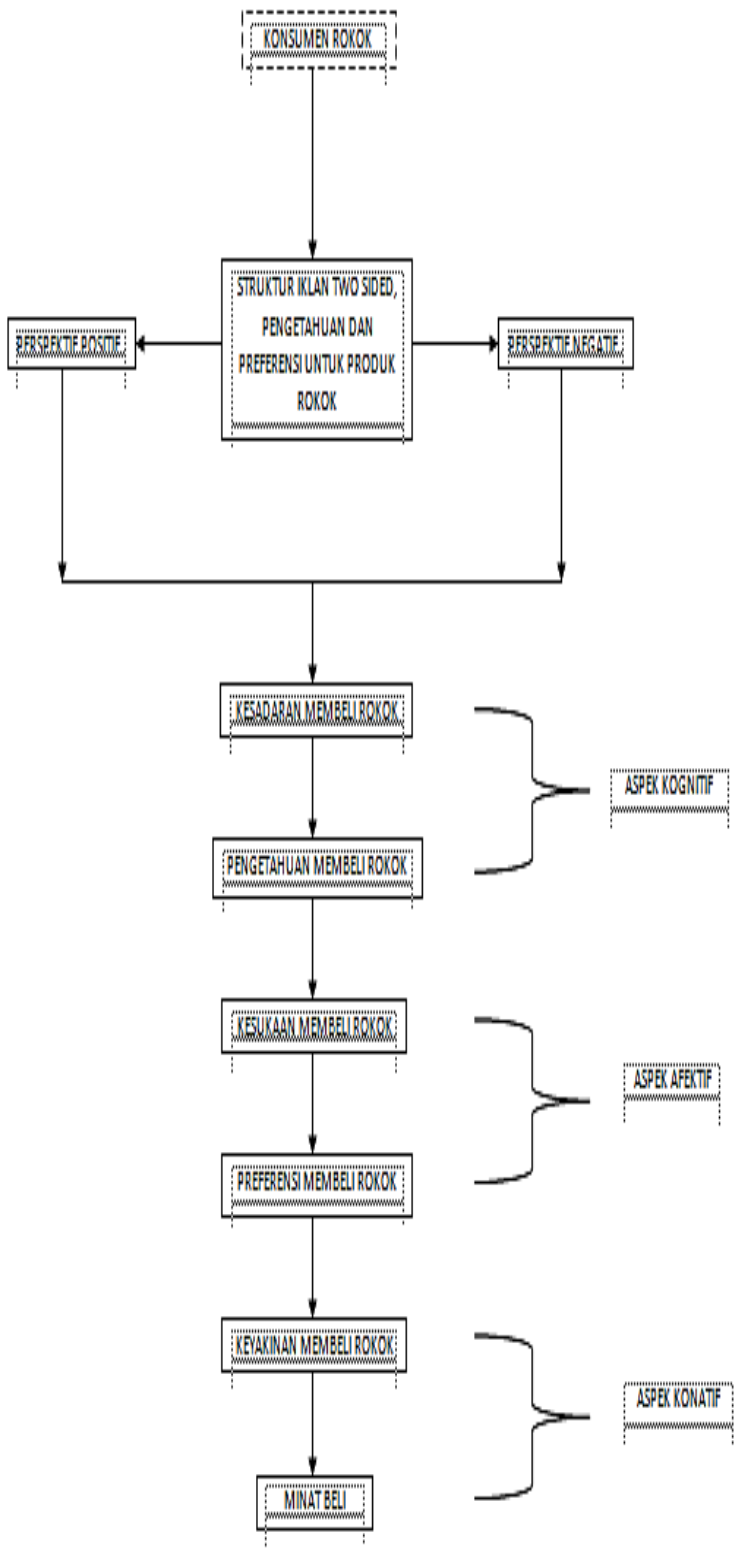

Gambar 1 Kerangka Konsep Penelitian 


\section{HASIL DAN PEMBAHASAN Uji Validitas}

Suatu instrument yang dikatakan valid, apabila mampu mengukur apa yang diinginkan, sebab suatu instrument yang dikatakan valid apabila suatu instrument penelitian dapat mengungkapkan data dari variabel yang diteliti. Nilai rhitung yang berada dalam kolom Corrected item table Correlation. Pada lembar output SPSS Pengujian validitas selengkapnya dapat dilihat pada tabel 2 Dibawah ini :

\section{Hasil Uji Validitas Variabel Iklan Two Sided $\left(\mathbf{X}_{1}\right)$}

\section{Tabel 2}

Hasil Uji Validitas Variabel Iklan Two Sided $\left(\mathbf{X}_{1}\right)$

\begin{tabular}{llcc}
\hline No & Item & R Hitung & Keterangan \\
\hline 1. & ITS1 & .492 & Valid \\
2. & ITS2 & .591 & Valid \\
3. & ITS3 & .597 & Valid \\
4. & ITS4 & .617 & Valid \\
$\mathbf{5 .}$ & ITS5 & .571 & Valid \\
$\mathbf{6 .}$ & ITS6 & .768 & Valid \\
7. & ITS7 & .668 & Valid \\
$\mathbf{8 .}$ & ITS8 & .665 & Valid \\
\hline
\end{tabular}

Sumber : Data Primer Penelitian Diolah, 2018

Berdasarkan hasil uji validitas ditabel 2 diketahui untuk variabel Iklan Two Sided pertanyaan 1 sampai 8 valid karena nilai corrected item total correlationnya lebih dari $r$ tabel yaitu 0,317 .

Hasil Uji Validitas Variabel Pengetahuan dan kesadaran $\left(\mathrm{X}_{2}\right)$

Tabel 3

Hasil Uji Validitas Variabel Pengetahuan dan kesadaran $\left(\mathbf{X}_{2}\right)$

\begin{tabular}{llcc}
\hline No & Item & R Hitung & Keterangan \\
\hline 1. & PK1 & .546 & Valid \\
\hline 2. & PK2 & .687 & Valid \\
\hline 3. & PK3 & .660 & Valid \\
\hline 4. & PK4 & .666 & Valid \\
\hline 5. & PK5 & .651 & Valid \\
\hline 6. & PK6 & .547 & Valid \\
\hline
\end{tabular}

\begin{tabular}{llcc}
\hline 7. & PK7 & .304 & Valid \\
\hline 8. & PK8 & .427 & Valid \\
\hline 9. & PK9 & .483 & Valid \\
\hline 10. & PK10 & .445 & Valid \\
\hline 11. & PK11 & .378 & Valid \\
\hline $\begin{array}{l}\text { Sumber : } \\
\text { 2018 }\end{array}$ & Data & Primer & Penelitian Diolah, \\
\end{tabular}

Berdasarkan hasil uji validitas ditabel 3 diketahui untuk variabel motivasi karyawan pertanyaan 1 sampai 10 valid karena nilai corrected item total correlationnya lebih dari $\mathrm{r}$ tabel yaitu 0,317 .

\section{Hasil Uji Validitas Variabel Preferensi dan Kesukaan $\left(\mathbf{X}_{3}\right)$}

Tabel 4

Hasil Uji Validitas Variabel Preferensi dan Kesukaan $\left(\mathbf{X}_{\mathbf{3}}\right)$

\begin{tabular}{llrc}
\hline No & Item & $\mathrm{R}_{\text {Hitung }}$ & Keterangan \\
\hline 1. & PK1 & .688 & Valid \\
\hline 2. & PK2 & .908 & Valid \\
\hline 3. & PK3 & .883 & Valid \\
\hline 4. & PK4 & .917 & Valid \\
\hline 5. & PK5 & .935 & Valid \\
\hline 6. & PK6 & .931 & Valid \\
\hline 7. & PK7 & .926 & Valid \\
\hline
\end{tabular}

Sumber : Data Primer Penelitian Diolah, 2018

Berdasarkan hasil uji validitas ditabel 4 diketahui untuk variabel Preferensi dan Kesukaan pertanyaan 1 sampai 7 valid karena nilai corrected item total correlationnya lebih dari $\mathrm{r}$ tabel yaitu 0,317 .

Hasil Uji Validitas Variabel Minat Beli (Y)

Tabel 5

Hasil Uji Validitas Variabel Minat Beli (Y)

\begin{tabular}{lccc}
\hline No & Item & $\begin{array}{c}\mathrm{R} \\
\text { Hitung }\end{array}$ & Keterangan \\
\hline 1. & MB1 & -.681 & Tidak Valid \\
\hline 2. & MB2 & .694 & Valid \\
\hline 3. & MB3 & .889 & Valid \\
\hline 4. & MB4 & .834 & Valid \\
\hline
\end{tabular}


Sumber : Data Primer Penelitian Diolah, 2018.

Seperti yang terlihat pada tabel diatas, dengan rhitung lebih besar dari $\mathrm{r}$ tabel sebesar 0,317 menunjukkan bahwa tiga alat ukur yang digunakan valid, hanya satu yang tidak valid yaitu pertanyaan nomor satu

\section{Reliabilitas}

Arikunto (2012 : 154)

menyatakan reliabilitas menunjukkan pada suatu Pengertian bahwa suatu instrumen cukup dapat dipercaya untuk digunakan sebagai alat pengumpul data karena instrumen tersebut sudah baik.

Pada penelitian ini, pengujian reliabilitas memakai bantuan program SPSS For Windows, yaitu dengan metode alpha. Besarnya koefisien nilai alpha yang diperoleh menunjukkan reliabilitas instrumen. Dari hasil perhitungan tersebut akan dapat diketahui tinggi rendahnya reliabilitas instrumen. Jika instrumen memiliki reliabilitas tinggi maka instrumen tersebut dapat dipercaya dan dapat diandalkan. Pengujian reliabilitas dengan metode Alpha Cronbach adalah dengan membandingkan koefisien Alpha $(\alpha)$ dengan 0,5. Jika koefisien Alpha ( $\mathrm{r}_{\text {hitung }}$ ) $>0,5$ maka item tersebut reliabel, sedangkan jika koefisien Alpha ( $\mathrm{r}_{\text {hitung }}$ ) < 0,5 , maka item tersebut tidak reliabel (Arikunto 2011:75). Hasil perhitungannya adalah sebagai berikut :

\section{Tabel 6}

\section{Pengujian reliabilitas Variabel Iklan} Two Sided $\left(\mathbf{X}_{1}\right)$

Reliability Statistics

\begin{tabular}{cc}
\multicolumn{2}{c}{ Reliability Statistics } \\
\hline $\begin{array}{c}\text { Cronbach's } \\
\text { Alpha }\end{array}$ & N of Items \\
\hline .868 & 8 \\
\hline
\end{tabular}

Berdasarkan hasil uji reliabilitas ditabel 4.5 menunjukkan bahwa variabel
Produktivitas kerja memiliki nilai yeng reliabel, hal ini dapat dilihat dari nilai cronbach's alpha yang lebih besar dari 0,6

\section{Tabel 7}

Pengujian Reliabilitas Variabel Pengetahuan dan Kesadaran $\left(\mathbf{X}_{2}\right)$

\begin{tabular}{cc}
\hline \multicolumn{2}{c}{ Reliability Statistics } \\
\hline $\begin{array}{c}\text { Cronbach's } \\
\text { Alpha }\end{array}$ & N of Items \\
\hline .843 & 11 \\
\hline
\end{tabular}

Berdasarkan hasil uji reliabilitas ditabel 7 menunjukkan bahwa variabel Lingkungan kerja memiliki nilai yeng reliabel, hal ini dapat dilihat dari nilai cronbach's alpha yang lebih besar dari 0,6

\section{Tabel 8}

Pengujian Reliabilitas Variabel Preferensi dan Kesukaan (X3)

\begin{tabular}{cr}
\hline \multicolumn{2}{c}{ Reliability Statistics } \\
\hline $\begin{array}{c}\text { Cronbach's } \\
\text { Alpha }\end{array}$ & N of Items \\
\hline .966 & 7 \\
\hline
\end{tabular}

\section{Tabel 9}

Pengujian reliabilitas Variabel Minat Beli (Y)

\begin{tabular}{|c|c|}
\hline \multicolumn{2}{|c|}{ Reliability Statistics } \\
\hline $\begin{array}{l}\text { Cronbach's } \\
\text { Alpha }\end{array}$ & $\mathrm{N}$ of Items \\
\hline .651 & 4 \\
\hline
\end{tabular}

Berdasarkan uji reliabilitas pada kedua variabel seperti yang terangkum pada tabel $6,7,8,9$ diketahui bahwa semua butir pertanyaan dalam variabel penelitian adalah handal. Sehingga butirbutir pertanyaan dalam variabel pertanyaan dapat digunakan untuk penelitian selanjutnya.

\section{Uji Asumsi Klasik}

Suatu model regresi yang baik harus memenuhi tidak adanya masalah asumsi klasik dalam modelnya. Jika masih terdapat asumsi klasik maka model regresi tersebut masih memiliki bias. Jika suatu model masih terdapat 
adanya masalah asumsi klasik, maka akan dilakukan langkah revisi model ataupun

Penyembuhan untuk menghilangkan masalah tersebut. Pengujian asumsi klasik akan dilakukan berikut :

\section{Uji Normalitas}

Uji Normalitas dipergunakan untuk melihat apakah sebaran data hasil penelitian terdistribusi secara normal atau tidak. Uji normalitas dilakukan dengan cara Normal P-P Plot. Hasil analisis regresi linier dengan grafik normal P-P Plot terhadap residual error model regresi diperoleh sudah menunjukan adanya pola grafik yang normal, yaitu

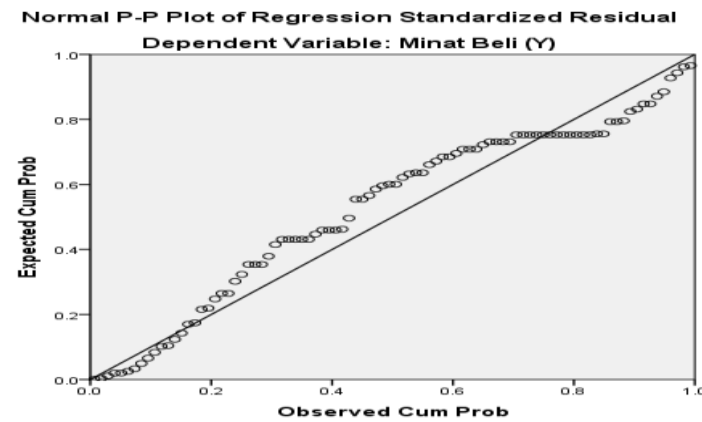

Gambar 2 Pengujian Normalitas

Hasil pengujian tersebut di atas menunjukan bahwa titik-titik berada tidak jauh dari garis diagonal. Hal ini berarti bahwa model regresi tersebut sudah terdistribusi normal

\section{Pengujian Heteroskedastisitas}

Pengujian heterokedastisitas bertujuan untuk mengetahui apakah dalam model regresi terjadi ketidaksamaan varians dari residual pengamatan yang lain dengan dasar pengambilan keputusan adalah sebagai berikut :

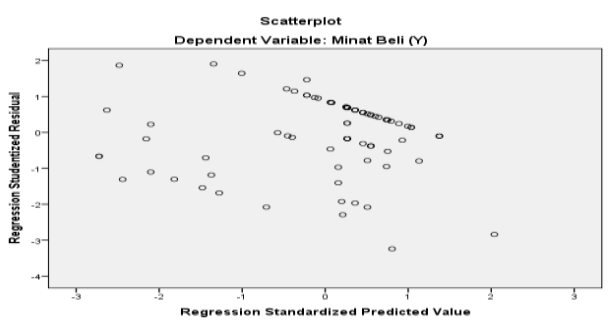

Gambar 3 Uji Heteroskedastisitas Analisis Hasil Penelitian

Analisis Verikatif dilakukan untuk membuktikan kebenaran dari hipotesis yang telah diajukan dalam penelitian ini dan dalam analisis verikatif ini

dilakukan beberapa pengujian statistik sebagai berikut :

\section{Pengujian Multikolonieritas}

Pengujian multikolonieritas
dilakukan dengan menggunakan nilaiVIF suatu variable menunjukan gejala multikolonieritas bias dilihat dari nilai VIF (Variance Inflation Factor) yang tinggi pada variable-variabel bebas suatu model regresi. Nilai VIF dari variabel bebas pada model regresi adalah sebagai berikut

\section{Tabel 10 Uji Multikolonieritas}

\begin{tabular}{lllc}
\hline & & Tolerance & VIF \\
\hline 1 & & \\
\cline { 2 - 4 } (Constant) & & \\
\cline { 2 - 4 } & Struktur Iklan \\
Two Sided (X1) & .529 & 1.891 \\
\hline $\begin{array}{l}\text { Pengetahuan } \\
\text { dan Kesadaran } \\
(\text { X2) }\end{array}$ & .602 & 1.661 \\
\hline $\begin{array}{l}\text { Preferensi dan } \\
\text { Kesukaan (X3) }\end{array}$ & .617 & 1.622 \\
\hline \multicolumn{1}{l}{ Hasil pengujian } & menunjukan
\end{tabular}

bahwa nilai VIF dari semua variabel bebas memiliki nilai yang lebih kecil dari 10. Hal ini berarti bahwa variablevariabel penelitian tidak menunjukan adanya gejala multikolonieritas dalam model regresi. 


\section{Deskriptif stastistik}

Analisis verikatif dilakukan untuk membuktikan kebenaran dari hipotesis yang telah dilakukan dalam penelitian ini dan analisis verikatif ini dilakukan. Beberapa pengujian statistik sebagai berikut :

Analisis regresi linier digunakan untuk membuktikan sejauh mana pengaruh struktur iklan two sided, pengetahuan dan kesadaran, preferensi dan kesukaan terhadap minat beli yang akan dianalisis dengan menggunakan bantuan program SPSS For Windows. Hasilnya adalah sebagai berikut :

\section{Tabel 11 Hasil Uji Regresi}

\begin{tabular}{|c|c|c|c|c|}
\hline \multicolumn{2}{|c|}{ Model } & \multicolumn{2}{|c|}{$\begin{array}{l}\text { Unstandardized } \\
\text { Coefficients }\end{array}$} & \multirow{2}{*}{$\begin{array}{c}\text { Standar } \\
\text { dized } \\
\text { Coeffic } \\
\text { ients } \\
\text { Beta }\end{array}$} \\
\hline & & B & $\begin{array}{l}\text { Std. } \\
\text { Error }\end{array}$ & \\
\hline \multirow[t]{4}{*}{1} & (Constant) & 6.397 & 4.017 & \\
\hline & $\begin{array}{l}\text { Struktur Iklan } \\
\text { Two Sided (X1) } \\
\end{array}$ & .635 & .096 & -.039 \\
\hline & $\begin{array}{l}\text { Pengetahuan dan } \\
\text { Kesadaran (X2) }\end{array}$ & .527 & .066 & .040 \\
\hline & $\begin{array}{l}\text { Preferensi dan } \\
\text { Kesukaan (X3) }\end{array}$ & .314 & .045 & .694 \\
\hline
\end{tabular}

Berdasarkan tabel 10 di atas yang diperoleh dari hasil uji regresi maka estimasi fungsi regresi yang diperoleh adalah :

$$
\mathrm{Y}=6,397+0,635 \mathrm{X} 1+0,527 \mathrm{X} 2
$$

$+0,314 \mathrm{X} 3+\mathrm{e}$

Persamaan regresi

tersebut dapat

dijelaskan sebagai

berikut :

1. Persamaan regresi linear berganda diatas, diketahui mempunyai nilai konstanta sebesar 6,397 dengan tanda positif. Sehingga besaran konstanta menunjukan bahwa jika variabelvariabel independen yaitu Struktur Iklan Two Sided (X1) Pengetahuan dan Kesadaran (X2), Preferensi dan Kesukaan (X3)diasumsikan dengan nilai konstan, maka variabel dependen yaitu keputusan masyarakat akan naik sebesar 6,397\%.

2. Nilai koefisien regresi X1 sebesar 0,635 artinya untuk setiap kenaikan 1 skor variabel Struktur Iklan Two Sided (X1) akan menaikkan skor minat beli (Y) sebesar 0,635.

3. Nilai koefisien regresi $\mathrm{X} 2$ sebesar 0,527 artinya untuk setiap kenaikan 1 skor

variabel Pengetahuan dan Kesadaran (X2) akan menaikkan skor minat beli (Y) sebesar 0,527

1. Nilai koefisien regresi $X 3$ sebesar 0,314 artinya untuk setiap kenaikan 1 skor variabel Preferensi dan Kesukaan (X3) akan menaikkan skor minat beli (Y) sebesar 0,314

\section{Uji F}

Pengujian pengaruh variabel bebas secara bersama-sama terhadap variable terikat dilakukan dengan menggunakan uji F. Hasil perhitungan statistik menunjukan nilai Fhitung = 11,373 dengan signifikansi sebesar 0,001 $<0,05$ Dengan nilai signifikansi dibawah 0,05 menunjukan bahwa secara bersamasama Iklan Two Sided dan pengetahuan dan kesadaran mempunyai pengaruh yang positif dan signifikan terhadap minat beli, hal ini berarti hipotesis diterima. Hasil perhitungan regresi secara bersama-sama diperoleh pada tabel 12 Berikut :

Tabel 12

Hasil Analisis Regresi Secara Bersama-sama

\begin{tabular}{llcc}
\hline Model & & $\mathrm{F}$ & Sig. \\
\hline \multirow{2}{*}{1} & Regression & 11.373 & $.001^{\mathrm{a}}$ \\
\cline { 2 - 4 } & Residual & & \\
\cline { 2 - 4 } & Total & & \\
\hline
\end{tabular}




\section{Koefisien Determinasi}

Koefisien determinasi ini digunakan untuk mengetahui seberapa besar pengaruh variable-variabel bebas memiliki pengaruh terhadap variabel terikatnya.

Nilai koefisien determinasi ditentukan dengan nilai adjusted $R$ square

Hasil dari pengolahan data yang menggunakan bantuan program SPSS, juga menghasilkan output berupa tabel koefisien model summary. Analisis koefisien determinasi ini menghasilkan gambaran seberapa signifikan pengaruh secara simultan variabel indevenden yakini Iklan Two Sided, kesadaran dan pengetahuan terhadap Minat Beli karyawan PT. Tanjung Enim Lestari Pulp and Paper Kabupaten Muara Enim seperti terlihat pada Tabel 4.12 berikut:

Tabel 13 Koefisien Determinasi

\begin{tabular}{|c|c|c|c|c|}
\hline Model & $\bar{R}$ & $\begin{array}{c}\mathrm{R} \\
\text { Squar } \\
\mathrm{e}\end{array}$ & $\begin{array}{l}\text { Adjusted } \\
\text { R Square }\end{array}$ & $\begin{array}{l}\text { Std. Error of } \\
\text { the Estimate }\end{array}$ \\
\hline 7 & $.769^{\mathrm{a}}$ & .824 & .795 & 5.304 \\
\hline
\end{tabular}

didapatkan tabel determinasi di atas yang memberikan $R$ Square sebesar 0,824. Hal ini menunjukan bahwa variabel Iklan Two Sided dan pengetahuan dan kesadaran secara simultan mempunyai pengaruh sebesar 0,824 atau $82,4 \%$ terhadap minat beli, sedangkan sisanya sebesar 17,6\% merupakan pengaruh dari (aspek) atau faktor-faktor lain yang tidak termasuk dalam penelitian ini seperti kesukaan dan preferensi dll. Sedangkan nilai korelasinya $(\mathrm{R})=0,769$. Hal ini menunjukkan bahwa variabel Iklan Two Sided dan pengetahuan dan kesadaran, korelasinya sangat kuat sekali terhadap minat beli. Menurut Nugroho, (2005:36), nilai korelasi (R) dapat dikelompokkan sebagai berikut : 0,41 s/d 0,70 korelasi keeratan kuat, 0,71 s/d 0,90 sangat kuat dan 0,91 s/d 0,99 sangat kuat sekali dan jika 1 berarti sempurna, namun bila nilai $(\mathrm{R})=0,824$ itu artinya nilai korelasi sangat kuat.

\section{Variabel Struktur Iklan Two Sided} (X1)

Hasil pengujian diperoleh nilai $\mathrm{t}$ untuk variabel tampilan iklan two sided menunjukan nilai $\mathrm{t}=3,871$ Dengan nilai signifikansi sebesar dengan nilai signifikansi sebesar $0,052<0,05$ dan dengan nilai dibawah 0,05 tersebut menunjukan bahwa iklan two sided memiliki pengaruh yang signifikansi terhadap minat beli. Hal ini berarti Hipotesis diterima. Arah koefisien regresi positif berarti bahwa iklan two sided memiliki pengaruh positif yang signifikan terhadap minat beli. Semakin baik iklan two sided yang ada akan semakin tinggi pula minat beli, sebaliknya semakin tidak baik iklan two sided yang ada semakin rendah pula minat beli. Hasil analisis kuantitatif menunjukkan bahwa variabel iklan two sided mempunyai pengaruh yang positif terhadap minat beli pada PT. Tell Pulp And Paper Berdasarkan hasil analisis, iklan two sided terhadap minat beli pada PT. Tell Pulp And Paper terhadap iklan two sided dan hal ini harus terus dipertahankan minat beli PT. Tell Pulp And Paper dapat lebih baik lagi, semakin tinggi iklan two sided yang diperlihatkan oleh PT. Tell Pulp And Paper maka akan mempengaruhi minat beli.

Variabel Pengetahuan dan Kesadaran

Hasil pengujian diperoleh nilai $t$ untuk variabel tampilan Pengetahuan dan Kesadaran menunjukan nilai $\mathrm{t}=3,083$ Dengan nilai signifikansi sebesar 0,022 $<0,05$ dengan nilai signifikansi dibawah 0,05 tersebut menunjukan bahwa harga memiliki pengaruh yang signifikansi terhadap minat beli. Hal ini berarti 
Hipotesis 2 diterima. Arah koefisien regresi positif berarti bahwa Pengetahuan dan Kesadaran memiliki pengaruh positif yang signifikan terhadap minat beli. Semakin baik harga yang ada akan semakin tinggi pula minat beli, sebaliknya semakin tinggi harga yang ada semakin rendah pula minat beli

\section{Variabel Preferansi dan Kesukaan}

Hasil pengujian diperoleh nilai $t$ untuk variabel tampilan Preferansi dan Kesukaan menunjukan nilai $\mathrm{t}=2,972$ Dengan nilai signifikansi sebesar 0,000 $<0,05$ dengan nilai signifikansi dibawah 0,05 tersebut menunjukan bahwa distribusi memiliki pengaruh yang signifikansi terhadap loyalitas konsumen. Hal ini berarti Hipotesis 3 diterima. Arah koefisien regresi positif berarti bahwa distribusi memiliki pengaruh positif yang signifikan terhadap minat beli. Semakin baik distribusi yang ada akan semakin tinggi pula minat beli, Sebaliknya semakin tidak baik minat beli yang ada semakin rendah pula minat beli.

\section{PENUTUP}

\section{Kesimpulan}

Adapun kesimpulan dan saran yang dapat dibuat pada laporan kemajuan ini adalah

1. Berdasarkan analisa regresi diperoleh koefisien determinasi (R-Square) yang diperoleh dari variabel-variabel independen terhadap minat beli adalah sebesar 0,873. Hal ini menunjukkan bahwa peningkatan terhadap minat beli adalah sebesar $87,3 \% \%$ artinya memberikan sumbangan efektif sebesar $87,3 \%$ dalam meningkatkan minat beli, sedangkan sisanya $12,7 \%$ dipengaruhi faktor faktor lain yang tidak diteliti dalam penelitian ini.
2. Sesuatu yang menarik dari hasil penelitian ini adalah bahwa meskipun tingkat kesadaran dan pengetahuan responden terhadap bahaya merokok bagi kesehatan adalah cukup tinggi, namun tingkat minat beli mereka terhadap produk juga tinggi. Bagi orang yang sudah terbiasa merokok, memang akan sulit melepaskan diri meskipun dijejali dengan berbagai anjuran untuk berhenti merokok, mengingat adanya berbagai faktor yang berpengaruh terhadap kebiasan merokok seperti faktor farmakologis, sosial dan psikologis.

3. Produk rokok tidak berpengaruh terhadap peferensi dan minat beli mahasiswa perokok YPP terhadap produk rokok. Artinya, informasi yang menujukkan sisi negative dari produk rokok yang berupa peringatan tentang pengaruh negative rokok bagi kesehatan tidak memengaruhi kesukaan, prefensi dan minat beli terhadap produk rokok.

\section{Saran}

1. Pemerintah perlu memikirkan suatu strategi untuk meningkatkan keefektifan peringatan bahaya merokok bagi kesehatan dalam iklan rokok sebab hasil penelitian ini menunjukkan bahwa peringatan tersebut tidak berpengaruh terhadap preferensi dan minat beli karyawan perokok PT. TEL Kabupaten Muara Enim. Misalnya penambahan durasi waktu penayangan peringatan tentang bahaya merokok, pembatasan waktu tayang iklan rokok, yaitu di malam hari setelah pukul 24 sampai dengan menjelang pukul 6 pagi waktu setempat dan memperbanyak pembuatan iklan layanan masyarakat tentang bahaya rokok. 
2. Sebagai wujud tanggung jawab social sebagai salah satu pelaku kegiatan pemasaran, produsen rokok perlu untuk mengimbangi kegiatan periklannya denagn kegiatankegiatan yang mendukung upaya penyadaran tentang bahaya merokok bagi kesehatan, seperti menjadi sponsor seminar, diskusi maupun kampanye tentang bahaya merokok.

3. Produsen rokok perlu melakukan sesuatu inovasi untuk menciptakan rokok yang tidak berbahaya bagi kesehatan.

4. Karena keterbatasan waktu, biaya dan tenaga maka bagi peneliti berikutnya perlu kiranya untuk melihat efektivitas iklan two sided dengan cara membandingkan dengan iklan one sided dan dengan jumlah responden yang lebih banyak serta priode pengamatan yang lebih panjang sebab iklan biasanya berpengaruh untuk jangka panjang.

\section{DAFTAR PUSTAKA}

Arikunto, Suharsimi. (2011). Prosedur Penelitian. Jakarta: Rineka Cipta.

Adiputra, Riyan \& Moningka. (2011). Gambaran Perilaku Konsumtif terhadap Sepatu pada Perempuan Dewasa Awal. PSIBERNETIKA : Jurnal Psikologi Jakarta, 5(2).

Basu Swasta, Dharmesta dan Irawan, (2011). Manajemen Pemasaran Modern. Yogyakarta: Liberty.

Dermawan Wibisono. (2010). Metode Penelitian \& Analisis Data. Jakarta: Salemba Medika.

Djarwanti \& Subagyo, Pangestu (2008), Statistik Induktif, Yogyakarta, BPFE.

Ghozali Imam. (2013). Aplikasi Analisis Multivariate Dengan Program
Ibm Spss 19, Semarang, Badan Penerbit Universitas Diponegoro

Kotler Philip \& Amstrong, Gary. (2011). Prinsip-prinsip Pemasaran Indoensia, Penerbit Erlangga.

Kasali, Rhenald. (2014). Manajemen Periklanan, Jakarta, PT. Pustaka Utama Grafika.

Lidyawati. (2008). Hubungan antara Intensitas Menonton Iklan di Televisi dengan Perilaku Konsumtif. Skripsi (tidak diterbitkan). Surakarta : Fakultas Psikologi UMS.

Moleong, Lexy J. (2014). Metodologi Penelitian Kualitatif, Bandung: Penerbit PT Remaja Rosdakarya Offset.

Pechmann, Cornelia. (2004). Predicting When Two-Sided Ads Will Be More Effective Than One Sided Ads : The Role of Correlational and Corespondent Inferences, Journal of Marketing Research, 29.

Wibisono, Dermawan. (2010). Riset Bisnis, Yogyakarta: Edisi Pertama, BPFE.

Sugiyono. (2012). Metode Penelitian Bisnis. Bandung: CV Alvabeta

Sugiyono, (2009). Metode Penelitian Kuantitatif, Kualitatif Dan R\&D. Bandung: Alfabeta.

Schiffman dan Kanuk. (2012). Bauran pemasaran , Edisi 7. Jakarta: Indeks.

Speziale, H.J., \& Carpenter, D. (2003). Qualitative research in nursing: Advancing the humanistic imperative. (3rd Ed.). Philadelphia, PA: Lippincott Williams \& Wilki 